\title{
PEMBERDAYAAN MASYARAKAT PENGEMBANGAN KAWASAN WISATA SUNGAI CIREONG KABUPATEN CIAMIS DALAM RANGKA PENGENTASAN KEMISKINAN
}

\author{
Marlina Nur Lestari*, Nina Herlina \\ Fakultas Ekonomi Universitas Galuh \\ *Email: marlina.nur.lestari@gmail.com
}

\begin{abstract}
ABSTRAK
Kawasan wisata mampu menjadi pendorong kemajuan perekonomian rakyat di daerah wisata. Diantaranya mampu meningkatkan penghasilan masyarakat, membuka peluang kerja, dan meningkatkan pendapatan pemerintah melalui retribusi wisata dan lain sebagainya. Masalah yang dihadapi saat ini adalah pengembangan wisata yang belum maksimal yang disebabkan minimnya pengetahuan tentang kewirausahaan (bisnis) yang dimiliki oleh pengurus kawasan wisata atau masyarakat sekitar kawasan wisata, padahal pengetahuan tentang kewirausahaan tersebut dapat dijadikan dasar untuk mempunyai ide bisnis dalam mengembangkan kawasan wisata. Kegiatan pengabdian ini dilakukan dengan cara memberikan penjelasan pada pengurus kawasan wisata mengenai kewirausahaan dan manajemen strategi dalam mengembangkan kawasan wisata. Kegiatan pengabdian dilakukan langsung di kawasan wisata sungai Cireong. Hasil yang dicapai dari kegiatan pengabdian ini pengurus kawasan wisata mendapatkan pengetahuan mengenai kewirausahaan, sehingga akan tercipta ide bisnis serta strategi untuk dapat mengembangkan kawasan tersebut yang ke depannya akan menjadi kawasan wisata yang berkembang dan berkelanjutan. Hal tersebut akan menjadi pendorong perekonomian di daerah dan selanjutnya dapat mengentaskan kemiskinan.
\end{abstract}

Kata kunci: Pemberdayaan masyarakat, kawasan wisata sungai Cireong

\section{PENDAHULUAN}

Salah satu upaya dalam pengentasan kemiskinan yaitu dengan menggali potensi wilayah beserta masyarakatnya. Kabupaten Ciamis mempunyai beberapa wilayah potensial yang dapat dijadikan lokomotif pertumbuhan ekonomi yang diharapkan dapat meningkatkan pendapatan masyarakat serta memberantas kemiskinan. Salah satunya adalah kawasan wisata sungai Cireong.

Kawasan wisata sungai Cireong terletak di desa Sukaresik, kecamatan Sindangkasih kabupaten Ciamis, dan sudah dijadikan kawasan wisata sejak tahun 2015 sebagai "sungai Cireong park". Apabila kawasan wisata tersebut dikelola dengan baik, maka kawasan ini sangat berpotensi untuk dapat menghasilkan pendapatan daerah bagi pemerintah kabupaten Ciamis dan meningkatkan pendapatan masyarakat sekitar sehingga dapat mengentaskan kemiskinan di daerah tersebut.

Kawasan wisata sungai Cireong ini masih alami, disertai dengan panorama yang indah, asri serta air sungai yang terus mengalir dengan air yang sangat jernih. Namun, karena kurangnya peran dari berbagai pihak terutama pemerintah daerah yang belum maksimal dalam mempromosikan dan mengembangkan kawasan wisata tersebut sehingga potensi kawasan wisata tersebut tidak berkembang secara maksimal.

Saat ini kawasan wisata sungai Cireong belum menunjukkan perkembangan yang maksimal ditandai dengan pengunjung yang tidak begitu banyak meskipun pada hari libur. 
Terlihat di kawasan wisata ini akses jalan menuju kawasan wisata yang sulit dilalui karena rusak, fasilitas umum kawasan wisata kurang memadai, masih kurangnya penjual makanan ataupun oleh-oleh khas daerah wisata, tidak ada taman bermain untuk anak-anak, juga belum ada sarana permainan air sungai seperti penyewaan perahu boat, dsb. Atas kekurangan tersebut, kawasan wisata sungai Cireong ini tidak memiliki daya saing dengan kawasan wisata yang lainnya. Hal ini dapat menyebabkan wisata sungai Cireong menjadi sulit berkembang. Efeknya kawasan wisata ini belum mampu meningkatkan pendapatan masyarakat dan mengentaskan kemiskinan daerah sekitar.

Tujuan dari pengabdian ini adalah: (1) Memberikan pengetahuan tentang kewirausahaan pada masyarakat kawasan sungai Cireong dalam rangka menumbuhkan ide bisnis, (2) Memberikan pengetahuan bagaimana menjalankan ide bisnis dalam mengembangkan kawasan sungai Cireong, dan (3) Memberikan pandangan dalam mengentaskan kemiskinan.

\section{BAHAN DAN METODE}

Khalayak sasaran pengabdian ini yaitu para pengelola kawasan sungai Cireong yang umumnya yaitu para pemuda dari masyarakat sekitaran sungai Cireong. Pelaksanaan kegiatan pengabdian pada masyarakat ini dilaksanakan melalui cara sebagai berikut:

1. Mengadakan pelatihan kewirausahaan untuk para pengelola kawasan wisata yang umumnya merupakan para pemuda dari warga sekitar sungai Cireong. Pelatihan tersebut berisi mengenai bagaimana melaksanakan suatu bisnis mulai dari perencanaan hingga pengontrolan, sehingga apa yang telah direncanakan dapat teralisasi.

2. Pelatihan diawali dengan cara membuat perencanaan bisnis dimulai dari strategi pemasaran sampai dengan pembuatan anggaran untuk mengembangkan kawasan wisata sungai Cireong yaitu berupa pengadaan permainan air juga penyewaan perahu boot sampai bisnis kuliner. Lalu diberikan cara dan jalan untuk mendapatkan modal dengan cara meminjam kepada lembaga keuangan yang menawarkan kredit khusus untuk UMKM. Dengan begitu para pengelola dapat menjalankan usahanya untuk meningkatkan pendapatan dan mengentaskan kemiskinan. Juga kawasan sungai Cireong dengan adanya permainan khas air sungai (arung jeram) ini dapat menjadi dasa saing bagi kawasan sungai Cireong, sehingga akan menarik wisatawan untuk datang pada kawasan ini.

Metode yang digunakan dalam kegiatan pengabdian kepada masyarakat ini meliputi pelatihan, diskusi dan penyuluhan sebagai berikut:

1. Pelatihan mengenai kewirausahaan beserta strategi manajemen yang baik dalam menciptakan dan menjalankan suatu usaha. 
2. Metode diskusi dan penyuluhan dilakukan untuk rencana pelatihan mengenai strategi manajemen mulai dari perencanaan sampai dengan pengontrolan.

Diharapkan setelah mengikuti pelatihan dan penyuluhan para pengurus kawasan wisata sungai Cireong dapat lebih produktif sehingga dapat meningkatkan pendapatan dalam rangka mengentaskan kemiskinan, dan juga kawasan wisata sungai Cireong dapat lebih berkembang sehingga memiliki daya saing dan dapat menarik wisatawan lebih banyak.

\section{HASIL DAN PEMBAHASAN}

\section{Sebelum Pengabdian}

Langkah pertama yang dilakukan sebelum pelaksanan pengabdian adalah survey lokasi ke kawasan wisata sungai Cireong Dusun Cireong, Desa Mekaersari, Kecamatan Singdangkasih, Kabupaten Ciamis dengan tujuan untuk melihat situasi dan kondisi lokasi kegiatan serta untuk mengurus perijinan.

Dari hasil survey terlihat bahwa masyarakat sekitar yang menjadi pengelola kawasan wisata tersebut tidak memiliki ide mengembangkan kawasan wisata, karena mereka intinya tidak memiliki ide untuk berbisnis padahal dengan ide bisnis tersebut selain dapat mengembangkan kawasan wisata juga dapat menambah pendapatan masyarakat dari berwirausaha.

Untuk itu dirasa perlu untuk memberikan penyuluhan mengenai kewirausahaan untuk pemuda sekitar juga pelatihan manajemen bagaimana cara mengawali suatu usaha (perencanaan). Langkah kedua yaitu membuat materi pelatihan, persiapan logistik dan konsumsi.

\section{Pelaksanaan Pengabdian}

Pelatihan dilaksanakan pada hari senin 3 Januari 2019 di rumah warga yang representatif di sekitar kawasan wisata tersebut. Pelatihan dimulai pukul 9.00 dan dihadiri oleh 10 peserta, 3 orang panitia dan 2 orang pemateri.

Sesi pertama dari jam 09.00 sampai 10.00 WIB. Materi penyuluhan pada sesi ini berupa kewirausahaan, membangun mindset bisnis, ide bisnis, merencanakan bisnis, memulai bisnis. Sesi kedua dari jam 10.00 sampai 12.00 wib dengan materi yang diberikan berupa bagaimana memulai suatu bisnis, dimulai dengan merancang sebuah anggaran, sampai dengan hal-hal yang perlu dipersiapkan untuk mendapatkan modal dari lembaga keuangan. 
Pemberdayaan Masyarakat Pengembangan Kawasan Wisata Sungai Cireong Kabupaten Ciamis Dalam Rangka Pengentasan Kemiskinan Marlina Nur Lestari, Nina Herlina

\section{Setelah Pengabdian}

Setelah pelatihan dilaksanakan dilakukan monitoring dan evaluasi pada pengelola kawasan sungai Cireong untuk melihat tindaklanjut dari pelaksana pengabdian. Dari hasil monitoring didapatkan adanya ide bisnis yang tercipta pada para pengelola yaitu merancang sebuah bisnis penyewaan perlengkapan air dan permainan air sungai, juga akan membangun bisnis kuliner dengan melakukan perencanaan yaitu membuat sebuah anggaran sehingga akan diperoleh angka kebutuhan modal kerja untuk dapat diajukan kepada lembaga keuangan. Setelah mendapatkan modal kerja tersebut, perencanaan bisnis akan terelalisasi.

\section{KESIMPULAN DAN SARAN}

\section{Kesimpulan}

Dengan adanya pelatihan kewitausahaan beserta strategi manajemen dalam merencanakan suatu bisnis, maka masyarakat sekitar yaitu para pemuda yang menjadi pengelola kawasan wisata telah mendapatkan pengetahuan tentang bagaimana memulai suatu bisnis/perencanaan suatu bisnis.

\section{Saran}

Perlu dilakukan pendampingan kepada masyarakat di lokasi wisata sungai Cireong yang dilakukan secara berkelanjutan agar lokasi wisata sungai Cireong dapat dimanfaatkan secara optimal untuk meningkatkan kesejahteraan masyarakat.

\section{DAFTAR PUSTAKA}

Dias Satria. (2009). Strategi Pengembangan Ekowisata Berbasis Ekonomi Lokal dalam Rangka Program Pengentasan Kemiskinan di Wilayah Kabupaten Malang. Journal of Indonesian Apllied Economics 3(1): 37-47.

Doddy Harris Dharmawan dan Adi Yunanto. (2016). Peluang Pariwisata dalam Menurunkan Kemiskinan di Era Masyarakat Ekonomi Asean (MEA). JERM 16(2): 199-213.

Erlangga Brahmanto, Harry Hermawan, Faizal Hamzah. (2017). Strategi Pengembangan Kampung Batu Malakasari Sebagai Daya Tarik Wisata Minat Khusus. Jurnal Media Wisata 15(2): 588-600.

Faris Zakaria dan Rimadewi Supriharjo, (2014). Konsep Pengembangan Kawasan Desa Wisata Di Desa Bandungan Kec Pakong Kab Pamekasan. Jurnal teknik ITS 3(2):

Gima SA. (2008). Metode Riset Bisnis dan Manajemen. Bandung: Gunadarma Intimarta.

Hary Hermawan. (2016). Dampak Pengembangan Desa Wisata Ngelanggeran Terhadap Ekonomi Masyarakat Lokal. Jurnal Pariwisata 3(2).

I Wayan Rusastra \& Togar A Napitupulu. (2010). Karakterristik Wilayah dan Keluarga Miskin di Pedesaan: Basis Perumusan Intervensi Kebijakan. https://pse.litbang.pertanian.go.id/ind/pdffiles/PROS_2008_MAK2.pdf. Diakses 02-092019. 


\section{ABDIMAS GALUH}

Volume 1, Nomor 1, September 2019, 22-26

Marcus J Pattinama. (2009). Pengentasan KemiskinanDengan Kearifan Lokal (Studi Kasus di Pulau Buru - Maluku dan Surade Jawa Barat)". Jurnal MAKARA SOSIAL HUMANIORA, 13(1).

Sefira Rialita Primadany. (2013). Analisis Strategi Pengembangan Pariwisata Daerah (Studi Pada Dinas Kebudayaan dan Pariwisata Daerah Kabupaten Nganjuk. Jurnal Administrasi Publik 1(4).

Sugiyono. 2014. Metode Penelitian Kuantitatif Kualitatif dan R\&D. Bandung: Alfabeta.

Tatag Muttaqin, Ris Hadi Purwanto dan Siti Nurul Rufiko. 2011. Kajian Potensi dan Strategi Pengembangan Ekowisata di Cagaralam Pulau Sempu Kab Malang Provinsi Jawa Timur. Jurnal Gamma 6(2).

UU RI No 2010 Tahun 2009 Tentang Kepariwisataan. 